\title{
EDITORIAL
}

\section{Entornos Virtuales Simulados y Realidad Virtual: Tecnologías que aportan a la Educación}

\author{
Simulated Virtual Environments and Virtual Reality: Technologies that \\ contribute to Education \\ Cleofé Genoveva Alvites-Huamaní \\ https://orcid.org/0000-0001-6328-6470 \\ Editor en Jefe de la revista cientifica Hamutay de la Universidad Alas Peruanas, Perú
}

\section{Cita Recomendada}

Alvites-Huamaní, C. (2019). Entornos Virtuales Simulados y Realidad Virtual Tecnologías que aportan a la Educación. Hamut'ay, 6(3), 5-9.

http://dx.doi.org/10.21503/hamu.v6i3.1840

El aporte que las instituciones educativas deben brindar a la comunidad en general, no solo debe basarse en la enseñanza, sino en buscar herramientas tecnológicas que permitan a los estudiantes desarrollar competencias idóneas a su campo laboral y que de alguna manera los sitúe en contextos similares que enfrentarán en su vida profesional. Martínez et al., (2007) menciona que la educación debe responder a las necesidades de la sociedad del conocimiento y proveer una formación enfocada en enseñanzas específicas. Asimismo, buscar que los estudiantes en formación cumplan con un perfil idóneo exigido por el mercado laboral, debiendo haber un engranaje entre formación y empresa; por lo que se torna necesario e imprescindible buscar alternativas de solución, lo cual se puede hacer plausible con el uso de recursos tecnológicos y sistemas expertos aplicados al ámbito educativo. Herrera et al., (2012) refieren que las tecnologías son cada vez más usadas en el quehacer educativo al contar con herramientas virtuales y sistemas multimedia para diferentes niveles educativos, pues estos medios o herramientas ayudan como soporte a la formación de los estudiantes.

\section{Entornos virtuales de simulación y aprendizaje}

Los cambios experimentados en la educación superior por el avance vertiginoso que ha tenido las
The contribution that educational institutions should offer to the community in general, should not only be based on teaching, but should also seek technological tools that allow students to develop skills suitable for their field of work and that in some way place them in contexts similar to those they will face in their professional life. Martinez et al. (2007) mentions that education should respond to the needs of the knowledge society and provide training focused on specific teachings. Likewise, the search for students in training to fulfill an ideal profile that is increasingly demanded by the labor market, there must be a gear between training and business, so it becomes necessary and essential to seek alternative solutions, which can be made plausible with the use of technological resources and expert systems applied to education. Herrera et al., (2012) refer that technologies are being used more and more in the educational task to have available virtual tools and multimedia systems for different educational levels, since these means or tools in some way help to support the training of students.

Virtual Simulation And Learning Environments

The changes experienced in higher education due to the dizzying advance of technologies have 
tecnologías han permitido generar nuevos espacios y formas de aprender, así como el tener en las aulas estudiantes que son nativos digitales, quienes piensan y procesan la información de manera diferente al tener en su quehacer diario a las tecnológicas, ya que viven y se alimentan de ella a cada momento, transcurriendo su vida en dos espacios, el virtual y el presencial, desde esta perspectiva para Calleja-Reina et al (2017); Chiecher, Donolo \& Corica (2013); Ruiz (2012) el uso de entornos virtuales de simulación y aprendizaje para la enseñanza es una alternativa idónea, ya que permite a los estudiantes poder experimentar en un entorno donde la reproducción artificial del mundo real es similar y donde la espontaneidad y la autonomía por parte del estudiante es constante al darle la opción de indagar, buscar soluciones al tener acceso abundante a diversas fuentes de información de manera inmediata, lo cual permiten la adquisición de competencias al estar frente a un ambiente bastante parecido al contexto real, donde se pueden realizar repeticiones de la situación problema las veces que desee y tener un mejor domino de la técnica o procedimiento que requiere en su especialidad. Carmona (2012); Aguirre (2012), refieren que los entornos de simulación y aprendizaje son una oportunidad para el estudio de una variedad de reacciones específicas y el que desarrollen habilidades de determinados procedimientos y destrezas que les ayudarán a afrontar situaciones similares, al permitir recrear escenarios semejantes a las actividades que realizarán en su profesión, pudiéndose observar que las respuestas dadas son similares a las que manifestaran en la vida real, lo cual da la opción a que se le pueda brindar una retroalimentación adecuada para que puedan ir desarrollando las competencias idóneas a su especialidad.

Casal (2016); Cataldi, Lage \& Dominighini (2013); Arbeláez (2012), enfatizan que estos entornos permiten adquirir y practicar conocimientos teóricos a través de la aplicación de casos o situaciones reales a la que se deben enfrentar los estudiantes en su campo laboral, sobre todo aquellos que tienen una relación directa con el trato de seres humanos, al dar la oportunidad a estos a que puedan equivocarse y practicar las veces que lo requieran hasta adquirir la competencia deseada. made it possible to generate new spaces and ways of learning, as well as to have students in the classrooms who are digital natives, who think and process information in a different way by having technology in their daily work, since they live and feed on it at every moment, spending their lives in two spaces, virtual and face-to-face, from this perspective for Calleja-Reina et al (2017); Chiecher, Donolo \& Corica (2013); Ruiz (2012) the use of virtual simulation and learning environments for teaching is an ideal alternative, as it allows students to experiment in an environment where the artificial reproduction of the real world is similar and where spontaneity and autonomy on the part of the student is constant by giving him the option to investigate, seek solutions by having abundant access to various sources of information immediately, which allow the acquisition of skills to be in an environment quite similar to the real context, where you can make repetitions of the problem situation as many times as you want and have a better mastery of the technique or procedure you require in your specialty. Carmona (2012); Aguirre (2012), refer that the simulation and learning environments are an opportunity for the study of a variety of specific reactions and the one that develop abilities of certain procedures and skills that will help them to confront similar situations, when allowing to recreate similar scenarios to the activities that they will carry out in their profession, being able to observe that the given answers are similar to those that they will manifest in the real life, which gives the option to which a suitable feedback can be given so that they can go developing the suitable competences to their specialty.

Casal (2016); Cataldi, Lage \& Dominighini (2013); Arbeláez (2012), emphasize that these environments allow students to acquire and practice theoretical knowledge through the application of real cases or situations they must face in their field of work, especially those that have a direct relationship with the treatment of human beings, by giving them the opportunity to make mistakes and practice as many times as they require until they acquire the desired competence. 


\section{Realidad Virtual (RV)}

Los cambios que ha traído consigo este siglo XXI en cuanto a los roles de docentes y estudiantes y la importancia abismal que ha tenido la educación superior en estos últimos años en nuestro país y la asistencia de miles de estudiantes en pro de tener una carrera universitaria, ha obligado a los centros de enseñanza superior a buscar estrategias pedagógicas acorde con el perfil de los estudiantes y los medios o recursos que estos utilizan con apropiación de la tecnología, como también lo aseveran Centella \& Hornero, (2017); Kerrigan, (2017); Delgado \& Moreno, (2012); González \& Chávez (2011) al mencionar que se debe diseñar nuevos escenarios educativos donde los estudiantes pueden aprender e intervenir en el nuevo espacio tecnológico con el cual nacieron, asimismo integrar el uso de la realidad virtual en la elaboración de instrumentos pedagógicos al permitir una comunicación multisensorial efectiva en las aulas, al ser una herramienta de aprendizaje en la cual el estudiante aprende haciendo, y se puede cumplir con los tres saberes, ser, saber y saber-hacer, ya que la RV ha ido emergiendo en todos los niveles educativos, por el apoyo que brinda al permitir recrear, diseñar, simular escenarios reales con fines educativos, de entrenamiento entre otros; así como el experimentar nuevas formas de comunicación de información y aprendizaje; según Gómez et al., (2013 p. 25); Monge et al., (2014) la RV es un entorno de simulación tridimensional interactiva por computadora en la que el estudiante se percibe en un mundo similar al real y puede evocar sensaciones y percepciones reales; Urra, Sandoval \& Irribarren (2017); Viñas-Diz \& Sobrido-Prieto (2015); Perpiña et al., (2012) refieren que la RV es una simulación de un entorno real a través de un ordenador, que permite al estudiante interactuar con ciertos elementos dentro de un escenario simulado, sin tener ningún riesgo y poder repetir la situación cuantas veces lo crea conveniente, al tener la posibilidad de interactuar de manera individual y grupal en tiempo real a través de avatares con fines educativos, lo que conlleva a un aprendizaje activo, participativo y colaborativo situando al estudiante como si estuviera presente en ese contexto.

\section{Virtual Reality (VR)}

The changes that this 21 st century has brought about in terms of the roles of teachers and students and the great importance that higher education has had in recent years in our country as well as the enrollment of thousands of students eager to have a university career, have forced higher education centers to look for pedagogical strategies according to the profile of the students and the means or resources that they use with the appropriation of technology, as Centella \& Hornero, (2017); Kerrigan, (2017); Delgado \& Moreno, (2012); González \& Chávez (2011) also state when they mention that new educational scenarios must be designed so that students can learn and intervene in this new technological space within which they were born; we should also integrate the use of virtual reality in the development of pedagogical instruments by allowing effective multisensorial communication in the classroom, being a learning tool in which the student learns by doing, fulfilling all three knowledges: know, know how to be and know how to do. VR has been emerging at all educational levels, making it possible to recreate, design and simulate real scenarios for educational, training purposes; as well as the use of an app for mobile cell phones in education as inclusive strategies, only with the aim of providing a better training, according to these times (López et al., 2019), and with new forms of communication of information and learning. According to Monge et al., (2014) VR is an interactive three-dimensional computer simulation environment in which the student perceives himself in a world similar to the real one and can evoke real sensations and perceptions; Urra, Sandoval \& Irribarren (2017); Vińas-Diz \& Sobrido-Prieto (2015); Perpiña et al., (2012) report that VR is a simulation of a real environment through a computer, which allows the student to interact with certain elements within a simulated scenario, without having any risk and being able to repeat the situation as many times as he considers it convenient, having the possibility of interacting individually and in groups in real time, through avatars, for educational purposes, which leads to active, participatory and collaborative learning, placing the student as if he or she were present in that context. 


\section{REFERENCIAS BibLIOGRÁFICAS}

Aguirre, G. (2012) Postura experiencial de los docentes de los docentes que utilizan la simulación clínica como estrategia didáctica en la carrera de medicina, Universidad Nacional de Colombia.

Arbeláez, M. (2012) Mundos virtuales para la educación en salud simulación y aprendizaje en Open Simulator. Tesis de Magíster. Universidad de Caldas, Colombia.

Calleja-Reina, M., Luque-Liñán, M. \& Rodríguez-Santos, J. (2017) Utilidad de una herramienta informática para la adquisición de competencia en razonamiento clínico en logopedia. Educ. Med. Recuperado de: https://doi.org/10.1016/j.edumed.2017.03.005

Carmona, J. (2012) Aplicaciones de la simulación tridimensional para la detección precoz de consumo de sustancias y violencia escolar en ámbitos educativos: Desarrollo y validación de una herramienta informática para su detección. Universidad de Almería.

Casal, M. (2016) La simulación como metodología para el aprendizaje de habilidades no técnicas en enfermería. (Tesis de doctorado) Universidad de Valencia, Espańa.

Cataldi, Z. Lage, F. \& Dominighini, C. (2013) Fundamentos para el uso de simulaciones en la enseñanza. Revista de Informática Educativa y Medios Audiovisuales, 10 (17), 8-16.

Centella, T. \& Hornero, F. (2017) Entrenamiento basado en la simulación: un cambio necesario en la formación de nuestra especialidad. Editorial. Cir Cardiov. https://doi.org/10.1016/j.circv.2017.03.002

Chiecher, A., Donolo, D. \& Corica, J. (2013) Entornos virtuales y aprendizaje: Nuevas perspectivas de estudio e investigaciones. Compilado IV, 1a edición, Mendoza-Argentina.

Delgado, G. \& Moreno, I. (2012) Aplicaciones de la Realidad Virtual en el trastorno por déficit de atención con hiperactividad: Una aproximación. Anuario de Psicología Clínica y de la Salud, 8, 31-39.

Gomez, G., Léon, R. Platas, S., Lechuga, M., Cruz, D. \& Hernández, A. (2013). Realidad Virtual y Psicoeducación. Formatos de Prevención selectiva en trastornos de la conducta alimentaria. Revista Mexicana de trastornos alimentarios, 4, 23-30.

González, A. \& Chávez, G. (2011) La realidad virtual inmersiva en ambientes inteligentes de aprendizaje. Un caso en la educación superior. Revista Icono 14, 9 (2), 122-137. https://doi.org/10.7195/ri14.v9i2.42

Herrera, G., Casas, X., Sevilla, J...Le Groux, S. (2012) Pictogram Room: Aplicación de tecnologías de interacción natural para el desarrollo del niño con autismo. Anuario de Psicología Clínica y de la Salud, 8; 41-46.

Kerrigan, N. (2017) Simulación, ¿una necesidad en el entrenamiento para la cirugía laparoscópica colorrectal? Revista Chilena de Cirugía. Recuperado de https://doi.org/10.1016/j.rchic.2017.06.004
Martínez, S., Bonet, P. Cáceres, P., Fargueta, F. \& García, E. (2007) Los objetos de aprendizaje como recurso de calidad para la docencia: criterios de validación de objetos en la Universidad Politécnica de Valencia. Recuperado de http:// ceur-ws.org/Vol-318/Naharro.pdf

Monge, E., Molina, F., Alguacil, I. Cano, R., De Mauor, A. \& Miangolarra, J. (2014) Empleo de sistemas de realidad virtual como método de propiocepción en parálisis cerebral: Guia de práctica Clínica. Neurología 29 (9), 550-559. https://doi.org/10.1016/j.nrl.2011.12.004

Viñas-Diz, S. \& Sobrido-Prieto, M. (2015) Realidad virtual con fines terapéuticos en pacientes con ictus: revisión sistemática. Neurología, 31 (4), 255-277. Recuperado de https://doi.org/10.1016/j.nrl.2015.06.012

Perpiña, C., Ferrero, A., Carrió, C. \& Roncero, M. (2012) Normalización de la ingesta en una paciente con anorexia nerviosa purgativa con el apoyo de un entorno virtual. Un estudio de caso.

Urra, E., Sandoval, S. \& Irribarren, F. (2017) El desafío y futuro de la simulación como estrategia de enseñanza en enfermería. Investigación en Educación Médica, 6 (22); 119125. https://doi.org/10.1016/j.riem.2017.01.147 